\title{
Kandungan Pigmen, Total Fenolik Dan Aktivitas Antioksidan Sargassum sp.
}

\author{
Sri Sedjati*, Endang Supriyantini, Ali Ridlo, Nirwani Soenardjo dan \\ Victorina Yulina Santi
}

\author{
Departemen IImu Kelautan, Fakultas Perikanan dan IImu Kelautan, Universitas Diponegoro \\ JI. Prof. Soedarto, SH. Kampus UNDIP Tembalang, Semarang 50275 \\ E-mail : sedjati69@gmail.com
}

\begin{abstract}
Pigmen content, total phenolic compound and antioxidant activity of the Seaweed Sargassum sp.

Sargassum sp. contains secondary metabolites which potentially act as natural source of antioxidant. The purpose of this study was to determine bioactive contents (pigments, total phenolic compounds), and antioxidant activities of Sargassum sp. The method of this research is descriptive-explorative. Sample was extracted with methanol, while pigments extraction with aseton $80 \%$. Chlorophyll a and carotenoids were carried out with spectrophotometer method. The total phenolic compounds were analyzed by spectrophotometer method using Follin-Ciocalteu reagent, and antioxidant activities were measured using DPPH (1,1-diphenyl-2- picrylhidrazyl) method. The result of this research showed that methanol extract of Sargassum sp. had the presence of chlorophyll a $2.84 \mathrm{mg} / \mathrm{g}$ and carotenoids $2.63 \mu \mathrm{mol} / \mathrm{g}$ sample. The total phenolic compounds of methanol extract were $57.97 \mathrm{mg} \mathrm{GAE} / \mathrm{g}$ sample. Methanol extract of Sargassum sp. was showing a strong antioxidant activity that could be seen in $I C_{50}$ value $(69,27$ ppm) in less than 100 ppm concentration.
\end{abstract}

Keywords: Sargassum sp.; methanol extract; total phenolic; antioxidant; IC 50

Abstrak

Sargassum sp. mengandung beberapa metabolit sekunder yang berpotensi sebagai sumber antioksidan alami. Tujuan dari penelitian ini adalah mengkaji komponen bioaktif (pigmen, total fenolik) dan aktivitas antioksidan dari rumput laut Sargassum sp. Metoda penelitian ini adalah diskriptif eksploratif. Sampel Sargassum sp. basah diekstraksi dengan cara maserasi dengan pelarut metanol, sedangkan ekstraksi pigmen menggunakan aseton $80 \%$. Penentuan kadar pigmen (klorofil a dan karotenoid), total fenolik dan aktivitas antioksidan berdasarkan metode spektrofotometri. Total fenolik diukur berdasarkan uji Follin-Ciocalteu, dan aktivitas antioksidan berdasarkan uji DPPH (1,1-diphenyl-2- picrylhidrazyl). Hasil penelitian menunjukan bahwa ekstrak metanol Sargassum sp. mengandung pigmen klorofil a sebesar 2,84 mg/g dan karotenoid sebesar $2,63 \mu \mathrm{mol} / \mathrm{g}$. Kadar total fenolik ekstrak metanol adalah $57,97 \mathrm{mgGAE} / \mathrm{g}$, sementara aktivitas antioksidannya (I $\left.\mathrm{C}_{50}\right)$ sebesar 69,27 ppm. Berdasarkan nilai I $\mathrm{C}_{50}$ nya, ekstrak metanol Sargassum sp berpotensi sebagai antioksidan kuat (kurang dari 100 ppm).

Kata kunci: Sargassum sp.; ekstrak methanol; total fenolik; antioksidan; IC 50

\section{PENDAHULUAN}

Radikal bebas dan oksidan lainnya semakin meningkat jumlahnya di alam kehidupan. Radikal bebas, reactive oxygen species (ROS) dan reactive nitrogen species
(RNS), dihasilkan baik dari sumber endogen (mitokondria, peroxisom, retikulum endoplasma, sel pagositosit, dll.) maupun eksogen (polusi, alkohol, rokok, logam berat, radiasi, dll.). Radikal bebas dapat merusak fungsi biologis molekul sel hidup, seperti: 
asam nukleat, lipid, dan protein, demikian pula dapat mengacaukan reaksi redoks dalam sel yang bisa memicu terjadinya oxidative stress (Lü et al., 2010; Mohammed et al., 2015 ; Phaniendra et al., 2015). Oxidative stress adalah suatu kondisi di mana jumlah radikal bebas terlalu besar melampaui kemampuan/kapasitas tubuh untuk meregulasi dan mengendalikannya. Kondisi tersebut menjadi penyebab timbulnya beberapa penyakit degenarif (Mohammed et al., 2015 ; Pizzino et al., 2017).

Oxidative stress terjadi ketika antioksidan internal dari dalam tubuh tidak mencukupi, solusinya adalah peningkatan input antioksidan eksternal. Sumber antioksidan bisa berasal dari bahan pangan fungsional yang mengandung di antaranya: vitamin ( $A, C$ dan $E$, pigmen karotenoid (karoten, likopen, lutein), dan senyawa golongan fenolik (flavonoid, flavon, flavonol) (Mohammed et al., 2015 ; Pizzino et al., 2017; Young and Lowe, 2018). Pigmen klorofil juga bermanfaat sebagai antioksidan (Hsu et al., 2013; Sudhakar et al., 2013 ; Rattaya et al., 2014).

Komponen aktif dari alga coklat sudah banyak diteliti. Berkaitan dengan sumber antioksidan alami, alga coklat termasuk tinggi kadar senyawa fenolik. Plorotanin adalah anggota keluarga senyawa fenolik yang spesifik ditemukan pada alga coklat, dan diketahui sangat kuat bioaktivitas antioksidannya (Le Lann et al., 2016 ; Sanjeewa et al., 2016). Alga coklat menghasilkan senyawa dengan bioaktivitas antioksidan lebih tinggi jika dibandingkan dengan alga merah dan hijau (Sudhakar et al., 2013). Ekstrak alkoholnya lebih berpotensi daripada ekstrak asetonnya (Seenivasan and Indu 2013). Namun, beberapa peneliti lain mengungkapkan hal berbeda. Ekstrak air panas dan kombinasi air dengan pelarut organik menghasilkan senyawa yang lebih berpotensi sebagai antioksidan, disebabkan kandungan senyawa fenolik dan polisakaridanya ( Giang et al., 2016; Sedjati et al., 2017)

Beberapa peneliti telah mengungkapkan potensi Sargassum sp. dari berbagai wilayah perairan Indonesia sebagai sumber antioksidan alami. Nurilmala et al. (2018) meneliti Sargassum sp. dari Kepulauan Seribu, Jakarta. Potensi antioksidan esktrak metanolnya termasuk kuat dengan $\mathrm{IC}_{50}$ sebesar $57,05 \mathrm{\mu g} \mathrm{mL}^{-1}$, kandungan Vitamin $\mathrm{E}$

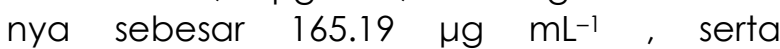
mengandung beberapa senyawa aktiv fenolik, flavonoid, dan triterpenoid. Bambang et al. (2013) meneliti Sargassum sp. dari perairan Sumenep, dan mengeksplorasi ekstrak etanol $S$. filipendula. Potensi antioksidannya juga tergolong kuat dengan $\mathrm{IC}_{50}$ sebesar $39,11 \mathrm{\mu g} \mathrm{mL}^{-1}$, serta mengandung total fenolik sebesar 12,87 mg GAE/g. Eksplorasi Sargassum sp. dari Pesisir Barat Aceh oleh Gazali et al. (2018) mendeteksi adanya senyawa fenol, alkaloid dan triterpenoid dalam rumput laut coklat tersebut. Kadar total fenol etanol ektrak $563,22 \mathrm{mg} \mathrm{GAE} / \mathrm{g}$ dengan $\mathrm{IC}_{50}=239,51 \mathrm{mgL}^{-1}$. Penelitian serupa oleh Septiana and Asnani (2013), menyebutkan bahwa kadar total fenolik ekstrak metanol S. duplicatum dari Pantai Nusa Kambangan sebesar 270,25 mg GAE/g.

Sargassum sp. kaya senyawa metabolit sekunder, seperti fenolik, flavonoid,tannin, sterol, terpenoid, saponin, alkaloid (Balanquit dan Fuentes, 2015 ; Baleta et al., 2017) dan terdapat juga glikosida (Waghmode dan Kumbar, 2015). Senyawa fenolik lebih aktiv sebagai antioksidan dibanding senyawa golongan lainnya. Gugus fungsional senyawa fenolik, O-H memiliki energi dissosiasi ikatan lebih rendah dibanding ikatan lainnya, seperti $\mathrm{N}-\mathrm{H}$, sehingga fenolik mudah melepaskan dan mendonorkan hidrogennya (Bendary et al. 2013).

Senyawa golongan terpenoid juga bisa berperan sebagai antioksidan, salah satunya adalah karotenoid. Karotenoid merupakan pigmen dominan di alga coklat, selain klorofil. Karotenoid yang banyak ditemukan pada alga coklat adalah : $\beta$-karoten, dan xantofil (fukoxantin, zeaxantin, lutein) (Zailanie dan Sukoso, 2014 ; Paransa et al., 2014). Karotenoid adalah pigmen yang memiliki peran utama proteksi sel tanaman terhadap proses fotooksidatif. Karotenoid mampu menetralkan molekul oksigen singlet dan radikal peroksil. Molekul karotenoid juga berperan dalam sistem pertahanan 
antioksidan pada manusia. Karotenoid bersinergi dengan antioksidan lain, dan campuran beragam karotenoid ternyata lebih efektif dibanding karotenoid tunggal (Stahl and Sies 2003). Manusia dan hewan tidak bisa mensintesa karotenoid, tetapi keberadaannya sangat penting dalam darah dan jaringan sebagai pertahanan terhadap radikal bebas (Fiedor dan Burda 2014).

Tujuan utama penelitian ini adalah mengetahui nilai aktivitas antioksidan yang terdapat pada ekstrak rumput laut Sargassum sp. yang diambil dari perairan Pantai Indrayanti, Gunung Kidul dengan menggunakan metode DPPH (1,1-difenil-2pikrilhidrazil). Selain itu, dianalisis juga kandungan senyawa-senyawa pendukung bioaktivitas antioksidan, berupa pigmen (klorofil $a, b$ dan karotenoid), dan kandungan total fenolik yang terdapat pada ekstrak rumput laut tersebut.

\section{MATERI DAN METODE}

Materi yang digunakan dalam penelitian ini adalah sampel segar rumput laut Sargassum sp.yang diperoleh dari Pantai Indrayanti, Gunung Kidul, Yogyakarta. Metode penelitian yang digunakan adalah diskriptif eksploratif.

Pengambilan sampel Sargassum sp. dilakukan pada waktu musim penghujan (Januari), menggunakan tangan langsung pada saat perairan surut. Sampel kemudian disimpan dalam plastik, selanjutnya dimasukan kedalam cool box yang telah diisi es. Preparasi sampel dimulai dengan pencucian dengan air tawar untuk menghilangkan kotoran, epifit dan pasir yang menempel. Sebanyak 250 gram sampel ditiriskan menggunakan kertas saring untuk mengurangi kadar air. Sampel dipotongpotong kecil berukuran $\pm 1 \mathrm{~cm}$ dengan menggunakan pisau, kemudian dihaluskan menggunakan blender.

Ekstraksi senyawa bioaktif dilakukan menggunakan metode maserasi (ekstraksi tunggal) dengan metanol teknis selama 24 jam pada suhu ruang $(3 \times$ pengulangan maserasi). Hasil maserasi disaring dengan kertas saring Wathman nomor 42. Filtrat dievaporasi dengan rotary evaporator pada suhu $40^{\circ} \mathrm{C}$ dan tekanan rendah. Ekstrak yang diperoleh disimpan dalam vial pada suhu rendah $\left(4^{\circ} \mathrm{C}\right)$ sebelum digunakan untuk analisis. Rendemen ekstrak dihitung menggunakan rumus:

Rendemen Ekstrak (\%) $=\frac{\text { Berat ekstrak }(\mathrm{g})}{\text { Berat sampel }(\mathrm{g})} \times 100 \%$

\section{Penghitungan \% Inhibisi}

Aktivitas antioksidan diukur menggunakan metode DPPH (Dhinakaran and Geetha 2015) dengan sedikit modifikasi. Larutan DPPH 0,1 mM, dibuat dengan cara melarutkan $4 \mathrm{mg}$ kristal DPPH dalam $100 \mathrm{ml}$ pelarut metanol p.a. 96\%. Larutan kontrol dibuat dengan mencampur larutan DPPH 1 $\mathrm{ml}$ ditambah metanol $3 \mathrm{ml}$. Sampel ekstrak dibuat menjadi 4 seri konsentrasi yaitu 15,625; 31,25; 62,5; dan 125 ppm. Sampel ekstrak dengan konsentrasi tersebut dibuat sebanyak $3 \mathrm{ml}$, kemudian ditambahkan dengan $1 \mathrm{ml}$ DPPH. Sampel diinkubasi selama 30 menit pada suhu $37{ }^{\circ} \mathrm{C}$ dan dianalisis serapannya terhadap DPPH menggunakan spektrofotometer UV-Vis pada panjang gelombang $517 \mathrm{~nm}$. Nilai persentasi inhibisi terhadap radikal bebas DPPH (aktivitas antioksidan) dihitung menggunakan rumus :

$$
\% \text { inhibisi }=\frac{\mathrm{Ac}-\mathrm{As}}{\mathrm{Ac}} \times 100 \%
$$

Keterangan : $\mathrm{Ac}=$ Absorbansi control; $\mathrm{As}=$ Absorbansi sampel. Inhibition Concentration $\left(\mathrm{IC}_{50}\right)$ ditentukan secara grafis menggunakan plot nilai hambatan dan konsentrasi ekstrak. Bentuk persamaan regresi linier yang diperoleh yaitu $y=b x+a$ dan persamaan garis yang diperoleh digunakan untuk menghitung Inhibitation Concentration 50\% $\left(\mathrm{IC}_{50}\right)$.

\section{Uji Total Fenol}

Pengujian kandungan total fenol mengacu pada metode yang dilakukan oleh Yangthong et al. (2009). Ekstrak padat Sargassum sp. $5 \mathrm{mg}$ dilarutkan kedalam $2 \mathrm{ml}$ pelarut metanol. Larutan kemudian 
ditambahkan $5 \mathrm{ml}$ akuades dan 0,5 ml FollinCiocalteu. Selanjutnya didiamkan selama 5 menit dan ditambahkan $1 \mathrm{ml} \mathrm{Na} 2 \mathrm{CO}_{3}$ (sodium karbonat) 5\%. Larutan dihomogenkan kembali dan diinkubasi selama 1 jam di tempat yang terhindar dari sinar matahari, kemudian dilakukan pengukuran serapan kandungan total fenol menggunakan spektofotometer UV-Vis pada panjang gelombang $725 \mathrm{~nm}$.

Kandungan senyawa fenolik yang terdapat dalam sampel ditentukan berdasar kurva standar asam galat dan diekspresikan dalam satuan mg ekuivalen asam galat/g ekstrak (mg GAE/g ekstrak) dengan rumus perhitungan :

$$
c=\frac{a x V / 1000}{G}
$$

Keterangan: $\mathrm{C}=$ total fenolik; $\mathrm{a}=$ konsentrasi asam galat $(\mathrm{mg} / \mathrm{L}) ; \mathrm{V}=$ volume larutan uji $(\mathrm{ml}) ; \mathrm{G}=$ massa ekstrak (g); $1000=$ faktor koreksi terhadap volume total larutan (ml)

\section{Uji Kadar Klorofil a, b dan Karotenoid}

Uji kadar klorofil $a, b$ dan karotenoid dilakukan menurut metode pengujian Lichtenthaler (1987). Prosedur pengujiannya adalah ekstrak ditimbang sebanyak $5 \mathrm{mg}$ dan dilarutkan dalam $5 \mathrm{ml}$ aseton p.a. $80 \%$, sehingga diperoleh larutan 1000 ppm. Absorbansi pigmen dibaca pada panjang gelombang 470, 646, dan 663 dan dianalisis.

Klorofil a $(\mathrm{mg} / \mathrm{g})=\left(12,21 \times \mathrm{A}_{663}\right)-\left(2,81 \times \mathrm{A}_{646}\right)$

$$
=\frac{\begin{array}{c}
\text { Karotenoid }(\mu \mathrm{mol} / \mathrm{g}) \\
(1000 \cdot \mathrm{A} 470)-(3,27 \cdot \mathrm{Ca})-(104 \cdot \mathrm{Cb})
\end{array}}{229}
$$

\section{HASIL DAN PEMBAHASAN}

Hasil ekstraksi 250 gram sampel segar rumput laut Sargassum sp.dengan pelarut metanol diperoleh ekstrak sebanyak 6,72 gram dengan rendemen sebesar $2,69 \%$. Ekstrak ini berbentuk pasta berwarna coklat pekat.

Hasil pengujian pigmen pada ekstrak metanol rumput laut Sargassum sp.menunjukan bahwa ekstrak mengandung pigmen klorofil a sebesar $2,84 \mathrm{mg} / \mathrm{g}$ dan karotenoid sebesar 2,63 $\mu \mathrm{mol} / \mathrm{g}$. Kandungan pigmen pada ekstrak metanol Sargassum sp. yang diduga sebagai sumber antioksidan adalah klorofil dan karotenoid. Menurut Sudhakar et al. (2013); Rattaya et al. (2014), senyawa karotenoid dan klorofil termasuk golongan senyawa antioksidan potensial. Penghilangan klorofil sebelum pengambilan ekstrak metanol maupun etanol ternyata menurunkan total fenolik dan kemampuan antioksidannya.

Kehadiran karotenoid dan klorofi Sargassum sp. dapat ditentukan dengan menggunakan spektrofotometer UV-vis (masing-masing $420 \mathrm{~nm}$ dan $672 \mathrm{~nm}$ )(Yip et al., 2014). Tampak pada Gambar 1, bahwa ekstrak pigmen Sargassum sp. didominasi oleh karotenoid. Berdasar penelitian

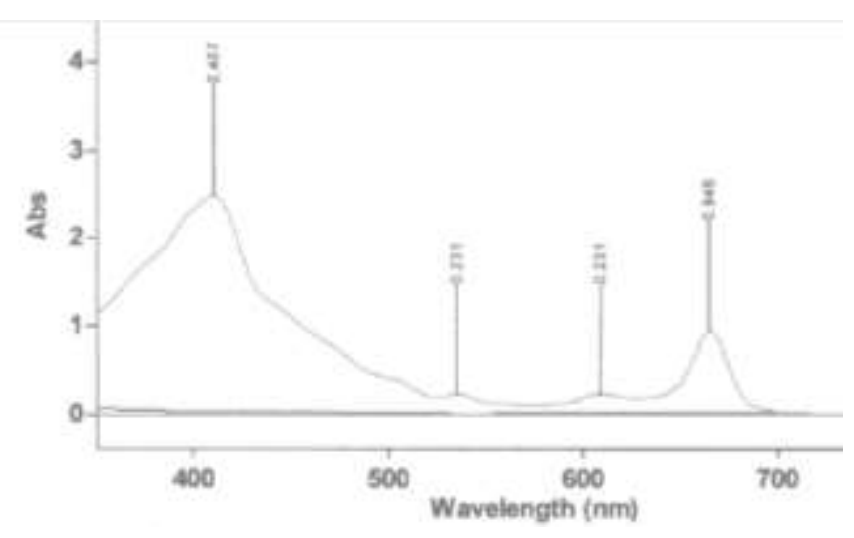

Gambar 1. Pola spektra ekstrak pigmen Sargassum sp. 
terdahulu, Indrawati et al.(2015), menyatakan bahwa Sargassum sp. mengandung karotenoid mayor, fukosantin, dan zeasantin, serta karotenoid minor $\beta$-karoten.

Senyawa karotenoid diduga mampu meredam oksigen singlet (singlet oxygen quenching) melalui ikatan konjugasi $\mathrm{C}=\mathrm{C}$ pada rantai karbon kerangka dasar polyene. Pigmen karotenoid juga dapat bereaksi dengan radikal peroksil (peroxyl radical scavenging) membentuk radikal karotenoid peroksil, kemudian berubah menjadi karotenoid peroksida yang bersifat kurang radikal dan mudah terurai, sehingga tidak berbahaya bagi sel hidup Beberapa pendapat menyatakan hal yang sama, sistem konjugasi melokalisir electron $\pi$ di sepanjang rantai polyene, sehingga karotenoid itu sendiri tidak terdegradasai akibat oksigen singlet. (Dutta et al., 2011; Young and Lowe, 2018).

Berkaitan dengan fungsi karotenoid sebagai radical scavenger, menurut Martínez et al. (2010), terdapat 3 kemungkinan reaksi antara senyawa karotenoid dan radikal bebas, yaitu :

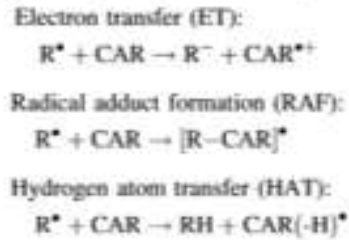

Sebuah molekul karotenoid mampu meredam paling sedikit dua radikal bebas dan menterminasi reaksi propagasinya. Molekul karotenoid yang berubah menjadi radikal tidak terlalu bahaya, karena waktu paruhnya singkat (mudah terdegradasi).

Karotenoid dominan pada Sargassum sp. adalah fukosantin. Gugus fungsi fukosantin terdiri dari alkohol, alkana, alkena, metil, ester dan alkena aromatic. Gugus alkohol dan aromatik berperan dalam mekanisme bioaktivitas antioksidannya (Renhoran et al. 2017).

Sargassum sp. mengandung beberapa gugus fungsional : (C-halida), ( $\mathrm{N}-\mathrm{O}),(\mathrm{C}=\mathrm{O})$, $(\mathrm{N}-\mathrm{H}),(\mathrm{C}-\mathrm{H})$ dan (O-H) (Sinjal et al. 2018). Senyawa fenolik diketahui terdapat di
Sargassum sp., minimal mengandung 1 gugus $\mathrm{O}-\mathrm{H}$, dan sebagian besar lebih dari satu (polifenol). Peranan senyawa fenolik sebagai antioksidan berkaitan dengan ikatan konjugasi di cincin aromatik benzenanya dan banyaknya gugus fungsional $\mathrm{OH}$.

Terdapat 2 mekanisme radical scavenging dari senyawa fenolik, yaitu donor atom $\mathrm{H}$ dan transfer elektron. Golongan senyawa fenolik seperti a-tokoferol, hydroxytyrosol, caffeic acid, dan asam galat berperan sebagai pendonor $\mathrm{H}$, sementara kaempferol dan resveratrol merupakan contoh dari pendonor elektron (Leopoldini et al. , 2004).

$$
\begin{aligned}
& \mathrm{R} \bullet+\mathrm{ArOH} \rightarrow \mathrm{RH}+\mathrm{ArO} \bullet \quad\left(\text { donoh } \mathrm{H}^{+}\right) \\
& \mathrm{R} \bullet+\mathrm{ArOH} \text { w R- }+\mathrm{ArOH} \bullet+\left(\text { donor } \mathrm{e}^{-}\right)
\end{aligned}
$$

Kemampuan antioksidan sebagai penangkap radikal bebas dikaitkan dengan kemampuan antioksidan tersebut sebagai pendonor proton maupun elektron. Berbagai senyawa fenolik dapat berperan terhadap penangkapan radikal bebas dengan kapasitas yang berbeda-beda.

Pengukuran total fenol ekstrak metanol didasarkan pada kurva standar menggunakan asam galat. Kadar total fenolik ekstrak metanol Sargassum sp. hasil penelitian adalah 57,97 $\mathrm{mgGAE} / \mathrm{g}$, sementara aktivitas antioksidannya (IC 50$)$ sebesar 69,27 ppm. Berdasarkan nilai IC 5onya, ekstrak metanol Sargassum sp berpotensi sebagai antioksidan kuat (kurang dari 100 ppm). Aktivitas antioksidan ekstrak Sargassum sp. ditentukan sesuai nilai $I_{50}$ yang diperoleh berdasarkan \% inhibisi DPPH $(1,1$ diphenil-2-pikrilhidrazil). Berdasarkan penelitian Sedjati et al. (2017), aktivitas antioksidan berkorelasi positif dengan total fenolik yang terkandung dalam suatu bahan.

Penentuan potensi antioksidan pada penelitian ini berdasar pada uji DPPH, sehingga mekanisme kerja antioksidan yang terukur hanya terbatas sebagai radical scavenger. Ekstrak metanol Sargassum sp. terbukti mampu meredam radikal bebas dengan cara mendonorkan elektron untuk radikal DPPH. Pigmen karotenoid terlihat mendominasi (Gambar 1), diduga karotenoid lebih berperan sebagai antioksidan 
Tabel 1. Nilai \% inhibisi dan IC 50 ekstrak metanol Sargassum sp.

\begin{tabular}{llll}
\hline No. & Konsentrasi $(\mu \mathrm{g} / \mathrm{ml})$ & \% inhibisi & IC $50(\mu \mathrm{g} / \mathrm{ml})$ \\
\hline 1. & 15,625 & 0,19 & \\
2. & 31,25 & 0,41 & 69,274 \\
3. & 62,50 & 0,72 & \\
4. & 125 & 0,85 & \\
\hline
\end{tabular}

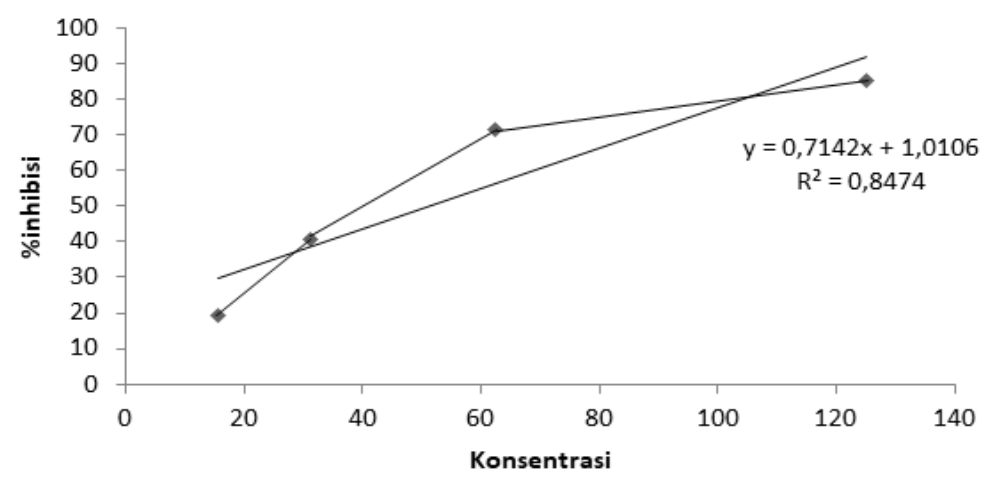

Gambar 2. Grafik hubungan konsentrasi ekstrak metanol Sargassum sp. dengan \% inhibisi DPPH

dibanding klorofilnya. Berdasar kepolaran aseton yang digunakan sebagai pelarut pigmen, dapat diprediksi bahwa karotenoid yang terekstrak adalah golongan xantofil. Xantofil adalah karotenoid yang gugusnya teroksigenasi dan bersifat relatif polar.

Fukoxantin merupakan karotenoid golongan xantofil yang banyak ditemukan di alga coklat, termasuk Sargassum sp.. Aktivitas antioksidan ekstrak metanolnya tidak terlepas dari kandungan fukoxantinnya yang relatif tinggi. Berdasar hasil penelitian Merdekawati dan Susanto (2009), Sargassum sp. mengandung $\beta$-karoten $(1,49 \%)$, dan fukoxantin $(20,95 \%)$ dari total pigmennya.

Kadar pigmen, total fenolik, maupun aktivitas antioksidan hasil penelitian ini tidak sama dengan penelitian-penelitian lain yang sejenis. Variasi ini diduga karena beberapa faktor : perbedaan spesies, perbedaan waktu panen, ataupun perbedaan lokasi. Faktor lain yang juga mempengaruhi adalah penentuan metode ekstraksi dan pemilihan jenis pelarut.

\section{KESIMPULAN}

Ekstrak metanol Sargassum sp.berpotensi sebagai sumber antioksidan alamiah. Aktivitas antioksidannya $\left(\mathrm{IC}_{50}\right)$ yaitu sebesar 69,27 ppm, nilai ini tergolong dalam kategori kuat karena kurang dari 100 ppm. Aktivitas antioksidan ekstrak metanol Sargassum sp. didukung oleh kandungan pigmen klorofil a sebesar $2,84 \mathrm{mg} / \mathrm{g}$ dan karotenoid sebesar 2,63 $\mathrm{\mu mol} / \mathrm{g}$, serta kandungan total senyawa fenolik sebesar $57,97 \mathrm{mgGAE} / \mathrm{g}$.

\section{DAFTAR PUSTAKA}

Balanquit, Brian Jann R., \& Rolly Fuentes, G. 2015. Preliminary Phycochemical Screening and Antioxidant Activity of Some Brown Algae Sargassum Species for Lawaan, Eastern Samar. J. Nature Stud. 14 (1): 12-21. DOI : 10.1017/CBO9 781107415324.004.

Baleta, Francis, N., Bolaños,J.M., Ruma, O.C., Baleta, A.N., \& Cairel, J.D. 2017. Phytochemicals Screening and Antimicrobial Properties of Sargassum Oligocystum and Sargassum Crassifolium Extracts. J. Med. Plants Stud.5(1):382-87.

Bambang, B.S., Kumalaningsih, S., Susinggih, W., \& Hardoko. 2013. Polyphenol Content and Antioxidant Activities of Crude Extract from Brown Algae by Various Solvents. J. Life Sci. Biomed. 3(6): 439-43. 
Bendary, E., Francis, R.R., Ali, H.M.G., Sarwat, M.I. \& El Hady, S. 2013. Antioxidant and Structure-activity Relationships (SARs) of Some Phenolic and Anilines Compounds. Annals Agricul. Sci. 58 (2): 173-81. DOI : 10.1016/j.aoas.2013.07.002.

Dhinakaran, Isaac, D., \& Geetha, P. 2015. Antioxidant Activities of Marine Algae Valoniopsis Pachynema and Sargassum Swartzii from the South East Coast of India. Int. J. Fish. Aqua. Stud. 3(2):426-30.

Dutta, D., Chaudhuri, U.R. \& Chakraborty, R. 2011. Structure, Health Benefits, Antioxidant Property and Processing and Storage of Carotenoids. African J. Food Agricul. Nut. Dev. 4(13):1510-20. DOI : 10.4314/ajfand.v4i13.71773.

Fiedor, Joanna, \& Burda, K. 2014. Potential Role of Carotenoids as Antioxidants in Human Health and Disease. Nutrients 6 (2): 466-88. DOI : 10.3390/nu6020466.

Gazali, Mohamad, Nurjanah, \& Zamani, N.P. 2018. Eksplorasi Senyawa Bioaktif Alga Cokelat Sargassum Sp. Agardh Sebagai Antioksidan Dari Pesisir Barat Aceh. J. Pengolahan Hasil Perikan. Ind. 21 (1):167. DOI : 10.17844/jphpi.v21i1.21543.

Hsu, C., Chao, P.Y., Hu, S.P \& Yang, C.M 2013. The Antioxidant and Free Radical Scavenging Activities of Chlorophylls and Pheophytins. Food Nut. Sci. 4:1-8. DOI : 10.4236/fns.2013.48A001.

Indrawati, Renny, Sukowijoyo, H., Indriatmoko, Wijayanti, R.D.E \& Limantara, L. 2015. Encapsulation of Brown Seaweed Pigment by Freeze Drying: Characterization and Its Stability during Storage. Proc. Chem. 14:353-60. DOI : 10.1016/j.proche.2015.03.048.

Le Lann, K., Surget, G., Couteau, C., Coiffard, L., Cérantola, S., Gaillard, F. \& Larnicol, M. 2016. Sunscreen, Antioxidant, and Bactericide Capacities of Phlorotannins from the Brown Macroalga Halidrys Siliquosa. J. App. Phycol. 28(6):3547-59. DOI : 10.1007/s10811-016-0853-0.

Leopoldini, Monica, Marino, T., Russo, N., \& Toscano, M. 2004. Antioxidant Properties of Phenolic Compounds: H-Atom versus Electron Transfer Mechanism. J. Physic. Chem. A 108 (22):4916-22. DOI : 10.1021 /jp037247d.

Lü, J.M.,Lin, P.H., Yao, Q., \& Chen, C. 2010. Chemical and Molecular Mechanisms of
Antioxidants: Experimental Approaches and Model Systems. J. Cell. Mol. Med. 14(4):840-60. DOI : 10.1111/j.1582-4934. 2009.00897.x.

Martínez, A., Vargas, R., \& Galano, A., 2010. Theoretical Study on the Chemical Fate of Adducts Formed through Free Radical Addition Reactions to Carotenoids. Theoretical Chemistry Accounts 127 (5): 595-603. DOI: 10.1007/s00214-010-0753-3.

Merdekawati, Windu, \& Susanto, A.B. 2009. Kandungan Dan Komposisi Pigmen Rumput Laut Serta Potensinya Untuk Kesehatan. Squalen. 4(2):41-47.

Mohammed, T.,, Kadhim, S.M., Noori, A.M. \& Abbas, S.I., 2015. Free Radicals and Human Health. Int. J. Innov. Sci. Res. 4(6):218-23.

Nair, Beena, B., Beena, B. M. P., Sudhakar, J. S. \& Ananthalakshmi, N. 2013. Research Article Extraction, Purification and Study on Antioxidant Properties of Fucoxanthin from Brown Seaweeds. J. Chem. Pharmaceut. Res. 5(7):169-75.

Nurjanah, Nurilmala, M., Anwar, E., Luthfiyana, N., \& Hidayat, T., 2017. Identification of Bioactive Compounds of Seaweed Sargassum sp. and Eucheuma cottonii Doty as a Raw Sunscreen Cream. Proc. Pakistan Academy Sci. 54:31 1-18.

Paransa, Darus, S.J., Kemer, K., Rumengan, A.P., \& Mantiri, D.M.H. 2014. Analisis Jenis Pigmen Dan Uji Aktivitas Antibakteri Ekstrak Pigmen Xantofil Pada Alga Coklat Sargassum Polycystum (C.Agardh). J. LPPM Bidang Sains Dan Teknol. 1 (1):90-96.

Phaniendra, Alugoju, Jestadi, D.B. \& Periyasamy, L. 2015. Free Radicals: Properties, Sources, Targets, and Their Implication in Various Diseases. Indian J.f Clinical Biochem. 30(1):1 1-26. DOI : 10.10 07/s12291-014-0446-0.

Pizzino, G., Irrera, N., Cucinotta, M., Pallio, G., Mannino, F., Arcoraci, F., Squadrito, F., Altavilla, D., \& Bitto, A. 2017. Oxidative Stress: Harms and Benefits for Human Health. Oxidative Med. Cell. Longevity DOI : 10.1155/2017/8416763. pp 1-13

Kumbar, R. 2015. Phytochemical Screening and Isolation of Fucoxanthin Content of Sargassum llicifolium. J. Pure App. Biosci 3(6):218-22. DOI : 10.18782/2320-7051. 2180. 
Rattaya, S., Benjakul, S. \& Prodpran, T. 2014. Extraction, Antioxidative, and Antimicrobial Activities of Brown Seaweed Extracts, Turbinaria Ornata and Sargassum Polycystum, Grown in Thailand. Int. Aqua. Res. 7(1):1-16. DOI : 10.1007/s40071-014-0085-3.

Renhoran, M., Noviendri, D., Setyaningsih, I. \& Uju. 2017. Extraction and Purification of Fucoxanthin from Sargassum Sp. as AntiAcne. J. Pengolahan Hasil Perikanan Ind. 20(2):370-79.

Sanjeewa, K.K.A., Kim, E.A., Son, K.T., \& Jeon, Y.J. 2016. Bioactive Properties and Potentials Cosmeceutical Applications of Phlorotannins Isolated from Brown Seaweeds: A Review. J. Photochem. Photobiol. B: Biology. 162:100-105. DOI : 10.1016/j.jphotobiol.2016.06.027.

Seenivasan, R., \& Indu, H. 2013. In Vitro Antioxidant Activity of Selected Seaweeds From Southeast Coast of India. Int. J. Pharm. Pharm. Sci. 5(2):47484.

Septiana, Aisyah Tri, and Ari Asnani. 2013. Antioxidan Activity of Sargassum Duplicatum Seaweed Extract. J. Teknol. Pertanian 14(2):79-86.

Sinjal, C.A., Rompas, R.M., Sumilat, D.A. \& Suryanto, E. 2018. Antioxidant and Photoprotective Activity of Brown Seaweed from North Sulawesi Coast. 11
(6): 121-33.

Stahl, W. \& Sies, H. 2003. Antioxidant Activity of Carotenoids. Mol. Aspects Med. 24 (6):345-51. DOI: 10.1016/S0098-2997(03) $00030-X$.

Sudhakar, M.P., Ananthalakshmi, J.S. \& Nair, B.B. 2013. Extraction, Purification and Study on Antioxidant Properties of Fucoxanthin from Brown Seaweeds. J. Chem. Pharm. Res. 5(7):169-75.

Yangthong, Monsuang, Nongporn HutadilokTowatana, and Wutiporn Phromkunthong. 2009. Antioxidant Activities of Four Edible Seaweeds from the Southern Coast of Thailand. Plant Foods for Human Nutrition 64(3):218-23. DOI : 10.1007/s $11130-009-0127-y$.

Yip, W.H., Lim, S.J., Mustapha, W.A.W., Maskat, M.Y. \& Said, M. 2014. Characterisation and Stability of Pigments Extracted from Sargassum Binderi Obtained from Semporna, Sabah. Sains Malay. 43(9):1345-54.

Young, A. \& Lowe, G. 2018. CarotenoidsAntioxidant Properties. Antioxidants 7 (2): 28. DOI : 10.3390/antiox7020028.

Zailanie, Kartini \& Sukoso. 2014. Study on of Fucoxanthin Content and Its Identification in Brown Algae from Padike Vilage Talango District, Madura Islands. J. Life Sci. Biomed. 4(1):1-3. 